\title{
Model Investigasi Berbantuan Geogebra pada Geometri Bidang
}

\author{
Della Maulidiya ${ }^{1}$, Agus Susanta $^{2}$, Nur Aliyyah Irsal $^{3}$ \\ ${ }^{1}$ Pendidikan Matematika JPMIPA FKIP Universitas Bengkulu \\ della.maulidiya@gmail.com \\ ${ }^{2}$ PGSD Jurusan IImu Pendidikan FKIP Universitas Bengkulu \\ agusunib@yahoo.com \\ ${ }^{3}$ Pendidikan Matematika JPMIPA FKIP Universitas Bengkulu \\ nuraliyyah.irsal@gmail.com
}

\begin{abstract}
Abstrak
Tujuan penelitian yang diulas dalam artikel ini yaitu mendeskripsikan hasil identifikasi aktivitasaktivitas investigasi berbantuan Geogebra yang dilakukan mahasiswa S1 Pendidikan Matematika Universitas Bengkulu untuk memecahkan masalah-masalah geometri bidang. Permasalahan yang diberikan pada mahasiswa meliputi konstruksi garis tinggi segitiga, konstruksi berbagai jenis segiempat, dan konstruksi segitiga dengan keliling terkecil dimana segitiga itu dibentuk dari titik-titik pada masingmasing sisi sebuah segitiga. Hasil penelitian menunjukkan mahasiswa melakukan investigasi berbantuan Geogebra dengan tahapan sebagai berikut: membaca berulang kali permasalahan untuk mengidentifikasi informasi yang dibutuhkan dan permasalahan yang harus diselesaikan, menuliskan kembali permasalahan dengan bahasa sendiri sehingga dapat menuliskan secara sistematis langkah-langkah investigasi, membandingkan proses konstruksi manual dan berbantuan Geogebra yang pernah dilakukan untuk menyelesaikan permasalahan baru, mengidentifikasi sifat dan prinsip obyek geometri yang sesuai dengan permasalahan konstruksi, dan melakukan strategi coba-coba (trial and error) untuk menyelesaikan permasalahan.
\end{abstract}

Kata Kunci: investigasi, geogebra, geometri bidang, pemecahan masalah

\section{PENDAHULUAN}

Kemampuan pemecahan masalah merupakan salah satu kemampuan yang perlu dimiliki mahasiswa pendidikan matematika sebagai calon pendidik matematika sehingga perlu diajarkan dalam perkuliahan. Mengajarkan pemecahan masalah (teaching about problem solving) difokuskan pada mengajarkan tentang langkah-langkah dan strategi pemecahan masalah melalui pemberian berbagai masalah (Kennedy, Tipss, \& Johnson, 2008). Pengenalan dan pengembangan berbagai strategi pemecahan masalah akan membantu mahasiswa untuk mengembangkan kemampuan - kemampuan: memahami permasalahan, menentukan dan menggunakan strategi pemecahan masalah yang sesuai, serta menguji solusi sesuai permasalahan.

Lingkungan dynamic geometry menurut Ozen dan Kose (2013) mendukung hubungan antara konstruksi masalah baru dan penggunaan strategi pemecahan masalah dengan kecenderunagan pemecahanan masalah tingkat tinggi. Dalam lingkungan yang demikian, peranan guru matematika adalah untuk mendukung dan mendorong siswa menemukan konsep dan hubungan-hubungan matematis untuk mengkonstruksikan konjektur mereka sendiri serta membuktikannya dengan penalaran yang tepat. Dengan cara ini, guru dapat memilih masalah yang tepat serta membangun beragam strategi dan perspektif sehingga siswa mereka nanti dapat mempelajari konsep matematika.

Bentuk penugasan unjuk kinerja yang dilakukan pada penelitian ini yaitu investigasi masalah geometri bidang dengan bantuan perangkat lunak Geogebra. Investigasi menurut Kennedy, Tipss, dan Johnson (2008) memiliki kelebihan yaitu "While investigating a problem, students explore and apply concepts and skills, expand idea, and draw conclusions." Konsep investigasi matematika menurut Hasek (2013) merupakan metode pengajaran matematika yang didasarkan pada aktivitas-aktivitas eksplorasi yang dilakukan peserta didik terhadap situasi-situasi matematis. Penugasan dalam bentuk unjuk kinerja merupakan salah satu penilaian yang sesuai untuk pengajaran tentang pemecahan masalah (Stiggins, 1994). Unjuk kinerja menurut Stiggins (1994 : 172) dapat memperlihatkan aktivitas-aktivitas pemecahan masalah yang dilakukan peserta didik. Dengan demikian penilaian tugas unjuk kinerja berupa investigasi dapat memberikan gambaran tentang capaian kemampuan pemecahan masalah peserta didik sehingga dapat digunakan untuk pengembangan pembelajaran yang mendukung peningkatan kemampuan pemecahan masalah (Van de Walle, 2008).

Hasil penelitian Hasek (2013) menunjukkan bahwa peserta pelatihan guru matematika memanfaatkan dengan baik kemampuan visualisasi geometri pada Geogebra. Peserta juga menggunakan dengan optimal fitur spreadsheet pada Geogebra untuk melakukan investigasi dengan beragam latar belakang 
kemampuan matematika. Selanjutnya pada penelitian Ozen dan Kose (2013), mahasiswa calon guru terlebih dahulu melakukan investigasi dalam lingkungan paper-pencil based selanjutnya dalam lingkungan dynamic geometry. Awalnya partisipan mengalami kesulitan pada lingkungan paper-pencil dan mereka tidak menemukan hubungan antara kedua segitiga pada masalah yang diberikan. Pada lingkungan dynamic geometry, partisipan melalui fase rekursif seperti konstruksi, eksplorasi, konjektur, validasi, dan justifikasi dalam proses pemecahan masalah. Ozen dan Kose (2013) mengungkapkan bahwa fitur "dragging (menyeret)" dan "measuring (mengukur)" pada perangkat dynamic geometry memberi kesempatan siswa untuk memahami masalah dan untuk menemukan solusi yang potensial. Selain itu proses justifikasi atas konjektur yang telah dibuat memungkinkan partisipan melewati proses pembuktian formal dengan membuat argumen bermakna mengenai relasi yang mereka temukan. Hal ini relevan dengan penelitian Subramanian (2005) yang menemukan bahwa penggunaan perangkat lunak geometri dinamis meningkatkan kinerja siswa untuk pembuktian. Kesimpulannya, dengan adanya penelitian Ozen dan Kose (2013) ini, calon guru diberi kesempatan menghadapi pengalaman memecahkan masalah yang tidak biasa. Dengan pengetahuan mereka mengenai pengalaman ini, mereka dapat menciptakan lingkungan belajar yang lebih kaya bagi siswa yang akan diajar nanti, serta menjadi sumber ide untuk pengembangan pembelajaran mereka.

Penelitian Yanik dan Ada (2013) dilakukan untuk mengobservasi proses berpikir geometris siswa, untuk memperoleh pengetahuan mendalam mengenai pembentukan konsep, dan mengeksplorasi keterampilan siswa dalam menciptakan dan mengklasifikasi bentuk-bentuk ketika dihadapkan pada proses konstruksi dengan menggunakan Cabri Geometry. Hasil penelitian Yanik dan Ada (2013) menunjukkan siswa pada umumnya menggunakan lingkaran untuk konstruksi persegi, segitiga sama kaki, dan segitiga sama sisi. Selain itu diperoleh pula informasi bahwa pembelajaran dengan Cabri Geometry memberi pengaruh positif terhadap pemikiran original dan kreatifitas siswa yang ditunjukkan dari siswa lebih suka membuat penjelasan matematis dibandingkan membuat definisi dengan memanfaatkan kemudahan fitur "dragging (menyeret)". Yanik dan Ada (2013) menemukan bahwa siswa membandingkan persegi, segiempat paling istimewa, dengan segitiga sama sisi, segitiga paling istimewa. Mereka mengeksplorasi kedua konstruksi bangun tersebut, dan membandingkan ciri umumnya. Siswa juga mengekspresikan urutan langkah pengerjaan dengan tepat. Ketika membuat urutan pengerjaan, siswa membangun beberapa strategi seperti " fokus pada fitur sudut dan sisi", "urutkan dari yang termudah sampai tersulit".

Penelitian yang telah dilakukan penulis ini bertujuan untuk mendeskripsikan hasil identifikasi aktivitas-aktivitas investigasi berbantuan Geogebra yang dilakukan mahasiswa S1 Pendidikan Matematika Universitas Bengkulu untuk memecahkan masalah-masalah geometri bidang. Mogetta, Olivero, dan Jones (1999) dalam Ozen \& Kose (2013) mengemukakan bahwa proses konstruksi, eksplorasi, dan justifikasi adalah fase utama dalam proses pemecahan masalah. Pada penelitian ini, dalam mengonstruksi bangun geometri, mahasiswa dituntut untuk terlebih dahulu mendefinisikan dan mendeskripsikan sifat-sifat bangun geometri yang akan dikonstruksikan. Mahasiswa diberikan pemahaman bahwa konstruksi memiliki makna berbeda dari membuat sketsa (sketch) ataupun menggambar (draw) di mana konstruksi harus memenuhi konsep dan prinsip geometri dengan benar. Setelahnya siswa diberi kesempatan untuk menginvestigasi caracara mengonstruksikan bangun geometri berdasarkan konsep dan prinsip dasar konstruksi geometri bidang menggunakan jangka dan penggaris terkait dengan sifat-sifat yang telah dideskripsikan. Proses investigasi ini juga selanjutnya juga dilakukan dengan bantuan perangkat lunak geogebra. Dengan perangkat lunak yang dinamis ini diharapkan membantu mahasiswa dalam memecahkan masalah konstruksi bangun geometri bidang. Oleh karena itu, kemampuan pemecahan masalah geometri bidang yang difokuskan dalam penelitian ini yaitu kemampuan mengkonstruksi bangun geometri untuk membuktikan suatu prinsip atau teorema terkait segitiga dan segiempat.

\section{METODE PENELITIAN}

Penelitian yang dilakukan oleh penulis merupakan penelitian deskriptif kualitatif dengan subyek yaitu mahasiswa S1 Pendidikan Matematika Universitas Bengkulu sebanyak 26 orang. Data diambil pada bulan September 2016 berupa : 1) hasil unjuk kinerja investigasi mahasiswa terhadap tiga masalah geometri bidang yang dilakukan dalam bentuk paper-pencil based dan program Geogebra, serta 2) jawaban angket respon mahasiswa. Hasil investigasi mahasiswa selanjutnya dinilai menggunakan rubrik penilaian untuk aspek dan komponen berikut : 1) aspek kognitif meliputi pemahaman masalah dan penarikan kesimpulan, 2) aspek psikomotorik terdiri dari proses konstruksi untuk investigasi berbantuan geogebra, dan 3) aspek afektif berupa kemandirian dalam melakukan investigasi. Hasil jawaban angket respon diolah menggunakan statistik deskriptif untuk menentukan prosentase jawaban siswa untuk 18 item pertanyaan. Pertanyaan pada angket respon terbagi menjadi empat aspek yaitu : 1) aktivitas yang dilakukan sebelum menjawab permasalahan, 2) aktivitas yang dilakukan selama menjawab permasalahan, 3) aktivitas yang dilakukan setelah menjawab permasalahan, dan 4) cara-cara atau teknik yang dilakukan untuk menjawab permasalahan. Keempat aspek tersebut dikembangkan berdasarkan kemampuan-kemampuan pemecahan masalah. 


\section{EKSPERIMEN DAN PEMBAHASAN}

Permasalahan yang diberikan pada mahasiswa meliputi tiga penugasan unjuk kerja secara individual. Tugas unjuk kerja pertama yaitu konstruksi garis tinggi segitiga. Tugas kedua yaitu konstruksi berbagai jenis segiempat. Dan tugas ketiga yakni konstruksi segitiga dengan keliling terkecil dimana segitiga itu dibentuk dari titik-titik pada masing-masing sisi sebuah segitiga. Identifikasi proses investigasi yang dilakukan mahasiswa pada Geogebra dapat dilakukan dengan mengaktifkan fitur Navigation Bar for Construction Steps yang mempresentasikan tahapan-tahapan konstruksi yang telah dilakukan mahasiswa.

Mahasiswa pada penugasan pertama diarahkan untuk membuat konstruksi garis tinggi sebuah segitiga sembarang dengan menggunakan jangka dan penggaris pada buku gambar polos ukuran A4. Setelah itu mahasiswa diminta untuk mengulangi proses konstruksi menggunakan Geogebra. Hasil observasi selama pembelajaran menunjukkan bahwa semua mahasiswa menggunakan lingkaran sebagai representasi jangka namun masih bergantung pada ukuran-ukuran tertentu yang terlihat dari penggunaan Grid, Axes, serta ukuran panjang sisi dan besar sudut. Meski demikian prinsip konstruksi dua garis tegak lurus dilakukan dengan baik oleh mahasiswa untuk konstruksi berbantuan Geogebra baik dengan menggunakan fitur $\Varangle$ Perpendicular Line atau pun dengan pemeriksaan sudut menggunakan $\aleph^{\circ}$ Angle . Berikut ditunjukkan enam variasi konstruksi garis tinggi segitiga sembarang yang dibuat mahasiswa pada Geogebra.

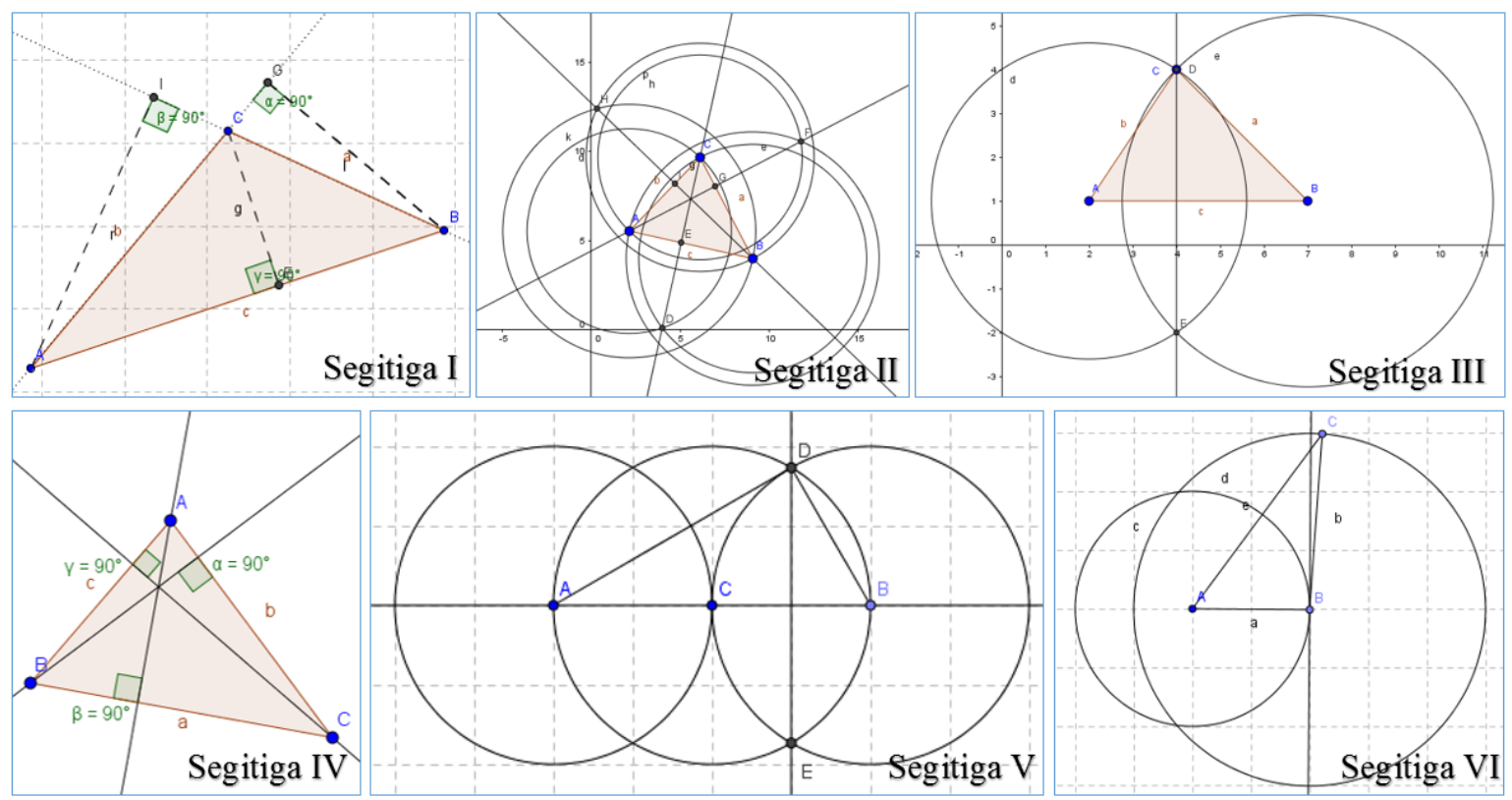

Gambar 1. Contoh konstruksi garis tinggi segitiga pada geogebra

Keenam konstruksi pada gambar 1 tersebut menunjukkan kecenderungan mahasiswa menggunakan segitiga lancip untuk melakukan investigasi. Hanya ada satu mahasiswa yang mencoba menentukan garis tinggi segitiga pada sisi dengan sudut tumpul. Sekitar 57,7\% mahasiswa membuat segitiga dengan alas yang tidak selalu mendatar pada konstruksi geogebra namun semua mahasiswa membuat segitiga dengan alas mendatar pada konstruksi manual. Hal ini menunjukkan adanya perubahan cara pikir dalam memvisualisasikan bentuk segitiga setelah menggunakan Geogebra. Hasil penelitian ini relevan dengan penelitian Yanik dan Ada (2013) dan Hasek (2013).

Mahasiswa kemudian ditugaskan untuk mengkonstruksi 7 jenis segiempat berbeda yaitu persegi, persegi panjang, belah ketupat, layang-layang, jajaran genjang, trapesium, serta sembarang segiempat tak beraturan. Konstruksi tersebut dilakukan dengan cara menginvestigasi sifat dan prinsip segiempat yang dapat digunakan untuk mengkonstruksi suatu segiempat tanpa ada ketentuan ukuran sisi atau pun sudut tertentu (ukuran sembarang). Mahasiswa pada awalnya menggunakan langkah yang serupa dengan konstruksi manual untuk membuat konstruksi berbantuan Geogebra. Setelah 2 atau 3 kali proses konstruksi pada Geogebra, mahasiswa selanjutnya menemukan teknik yang lebih cepat untuk menyelesaikan masalah konstruksi segiempat berbantuan geogebra. Berikut contoh konstruksi persegi secara manual (paper-pencil based) menggunakan jangka dan penggaris. 

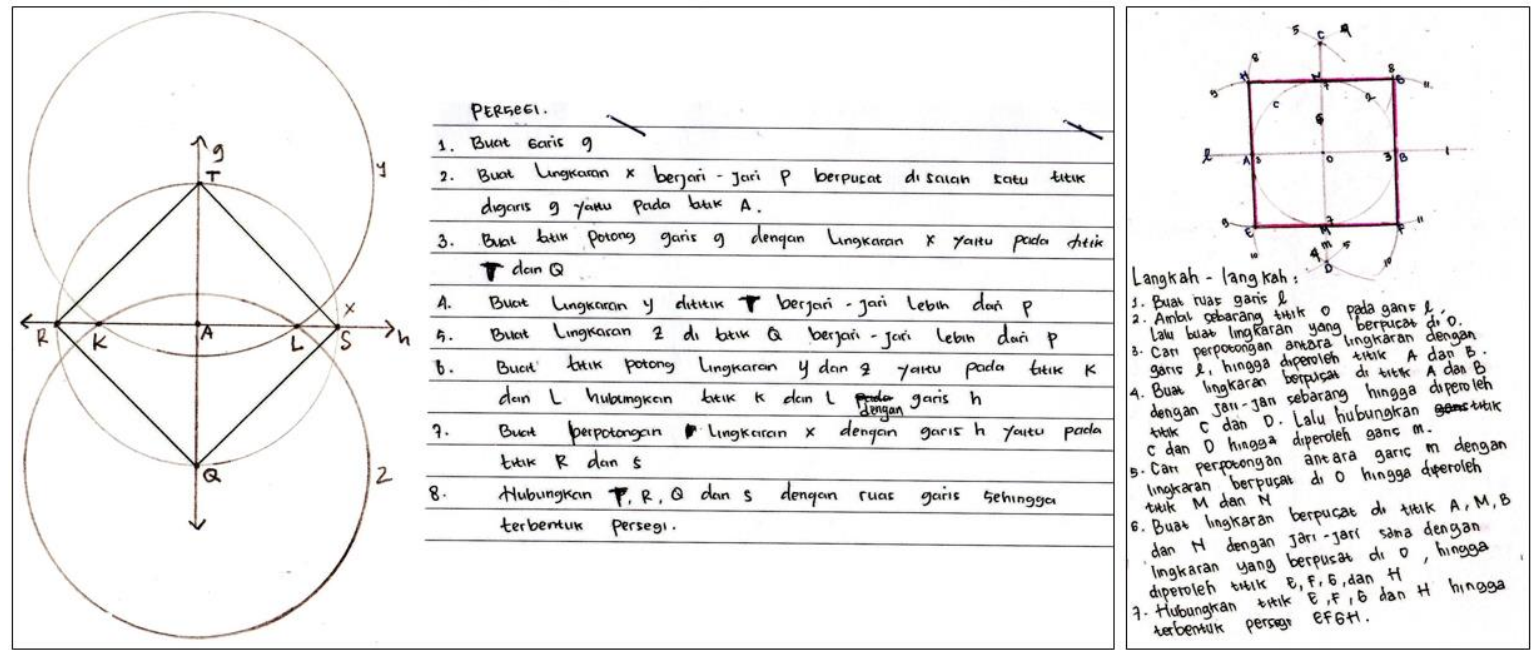

Gambar 2. Contoh Hasil Konstruksi Persegi Menggunakan Jangka dan Penggaris

Hasil konstruksi pada gambar 2 merupakan hasil akhir setelah melakukan berulang kali konstruksi dengan tahapan berbeda-beda. Konstruksi tersebut dilakukan sebelum menggunakan Geogebra. Berikut contoh hasil konstruksi persegi berbantuan geogebra yang menunjukkan ada delapan konstruksi berbeda.

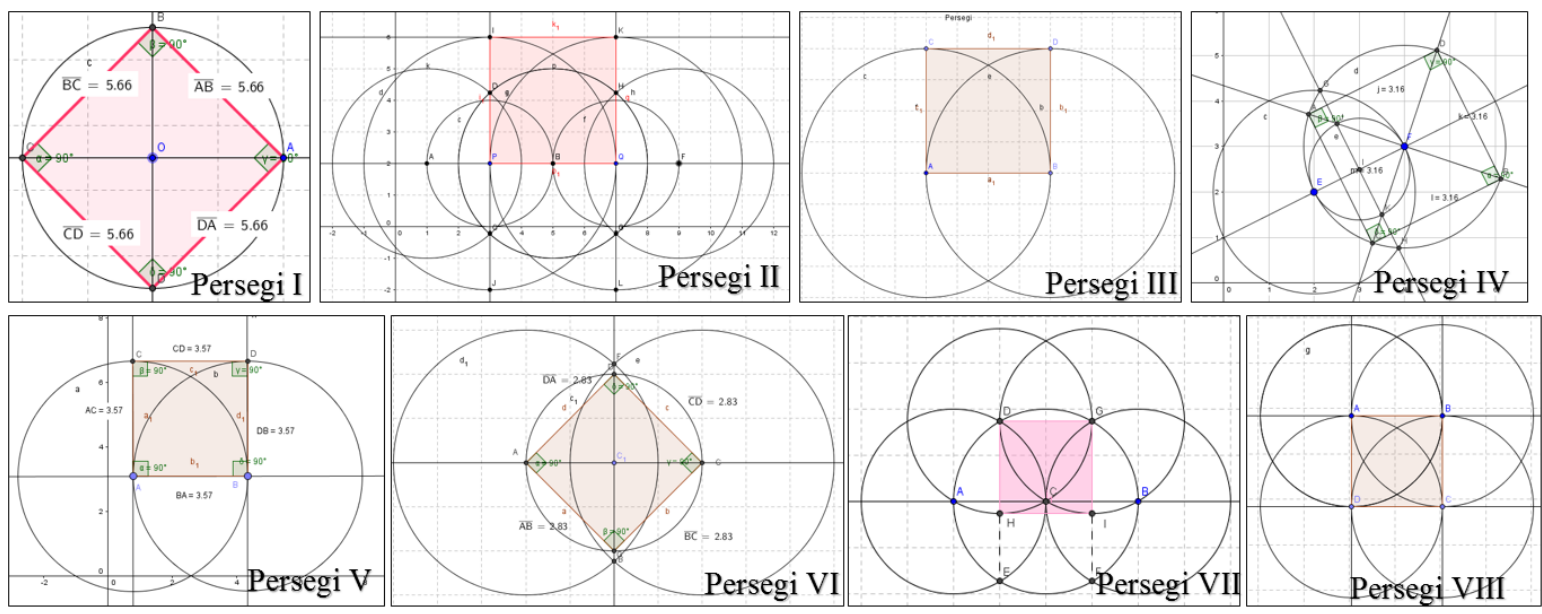

Gambar 3. Contoh Hasil Konstruksi Persegi Menggunakan Geogebra

Gambar 3 di atas memperlihatkan bahwa meskipun proses konstruksi persegi berbeda namun semua mahasiswa menerapkan prinsip konstruksi duplikasi ruas garis dan garis-garis yang saling tegak lurus. Sehingga tidak ada mahasiswa yang perlu melakukan pemeriksaan terhadap sifat sudut persegi. Berdasarkan identifikasi dari kedelapan konstruksi persegi diperoleh hasil berikut :

1) Sebagian besar mahasiswa menggunakan perpotongan dua lingkaran atau lebih untuk menentukan titiktitik sudut persegi, kecuali pada proses persegi I yang memanfaatkan diameter untuk menentukan titiktitik tersebut. Hal ini menunjukkan bahwa mahasiswa telah menerapkan prinsip konstruksi duplikasi ruas garis dan garis-garis yang saling tegak lurus.

2) Sebagian besar mahasiswa melakukan pemeriksaan terhadap ukuran sudut persegi dengan dengan menggunakan fitur ${ }^{\alpha}$. Angle (Persegi I, Persegi IV, Persegi V, Persegi VI).

3) Mahasiswa yang tidak melakukan pemeriksaan ukuran sudut persegi menggunakan fitur I Perpendicular Line untuk membuat sisi-sisi persegi yang membentuk sudut siku-siku (Persegi II, Persegi VII, dan Persegi VIII) dan menggunakan $\because$ Regular Polygon untuk membuat persegi (Persegi III)

Gambar berikut memperlihatkan contoh konstruksi trapesium menggunakan geogebra dengan memanfaatkan fitur lingkaran untuk menentukan titik-titik potong lingkaran-lingkaran yang kemudian dijadikan sebagai titik sudut trapesium. 


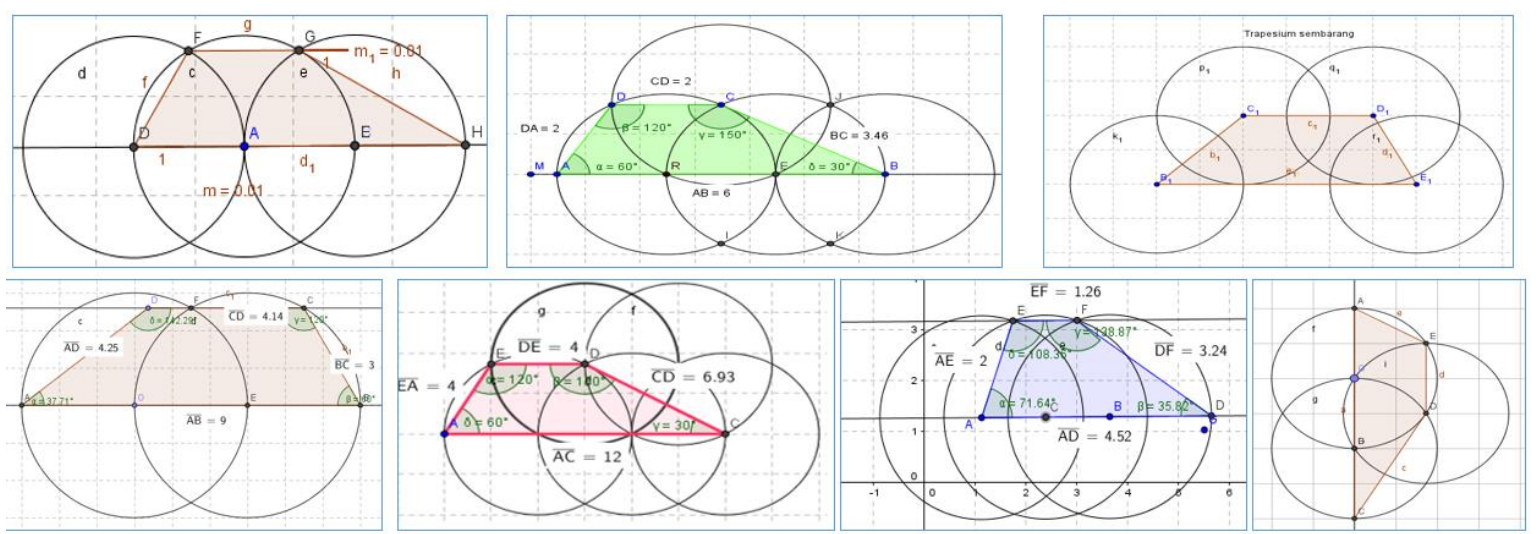

Gambar 4. Contoh konstruksi trapesium menggunakan Geogebra

Gambar 4 diatas memperlihatkan bahwa semua mahasiswa menggunakan sifat lingkaran kongruen, prinsip konstruksi lokasi titik pusat lingkaran, namun hanya sebagian mahasiswa yang menggunakan konstruksi garis tinggi segitiga, konstruksi garis-garis sejajar dan garis tegak lurus. Penentuan titik-titik sudut dilakukan dengan cara membuat lingkaran-lingkaran yang saling berpotongan dan memiliki diameter yang sama. Hanya ada dua mahasiswa yang menggunakan dua lingkaran saling berpotongan dan prinsip garis-garis sejajar untuk menentukan sisi-sisi trapesium. Pola konstruksi seperti ini dilakukan juga untuk membuat konstruksi jajaran genjang dan belah ketupat. Umumnya mahasiswa membutuhkan lebih dari dua lingkaran yang saling berpotongan untuk menentukan titik-titik sudut suatu bidang datar segiempat.

Tugas unjuk kerja ketiga yaitu menentukan prosedur konstruksi segitiga yang memiliki keliling minimum jika masing-masing titik-titik sudut segitiga tersebut berada pada sisi-sisi segitiga sembarang. Proses penyelesaian masalah ini dimulai oleh mahasiswa dengan membuat sketsa segitiga sembarang $\mathrm{ABC}$ kemudian menentukan titik-titik D,E, dan F pada masing-masing sisi segitiga ABC. Penyelesaian menggunakan konstruksi manual membutuhkan waktu yang cukup lama sekitar 2 jam dan tidak memberikan hasil yang benar meskipun telah diberikan sejumlah petunjuk yang berkaitan dengan penyelesaian masalah. Selanjutnya mahasiswa dibebaskan melakukan investigasi menggunakan bantuan Geogebra. Dalam waktu relatif singkat (sekitar 30 menit) mahasiswa mampu membuat penjelasan dan argumentasi penyelesaian masalah. Berikut contoh konstruksi masalah keliling segitiga berbantuan geogebra.
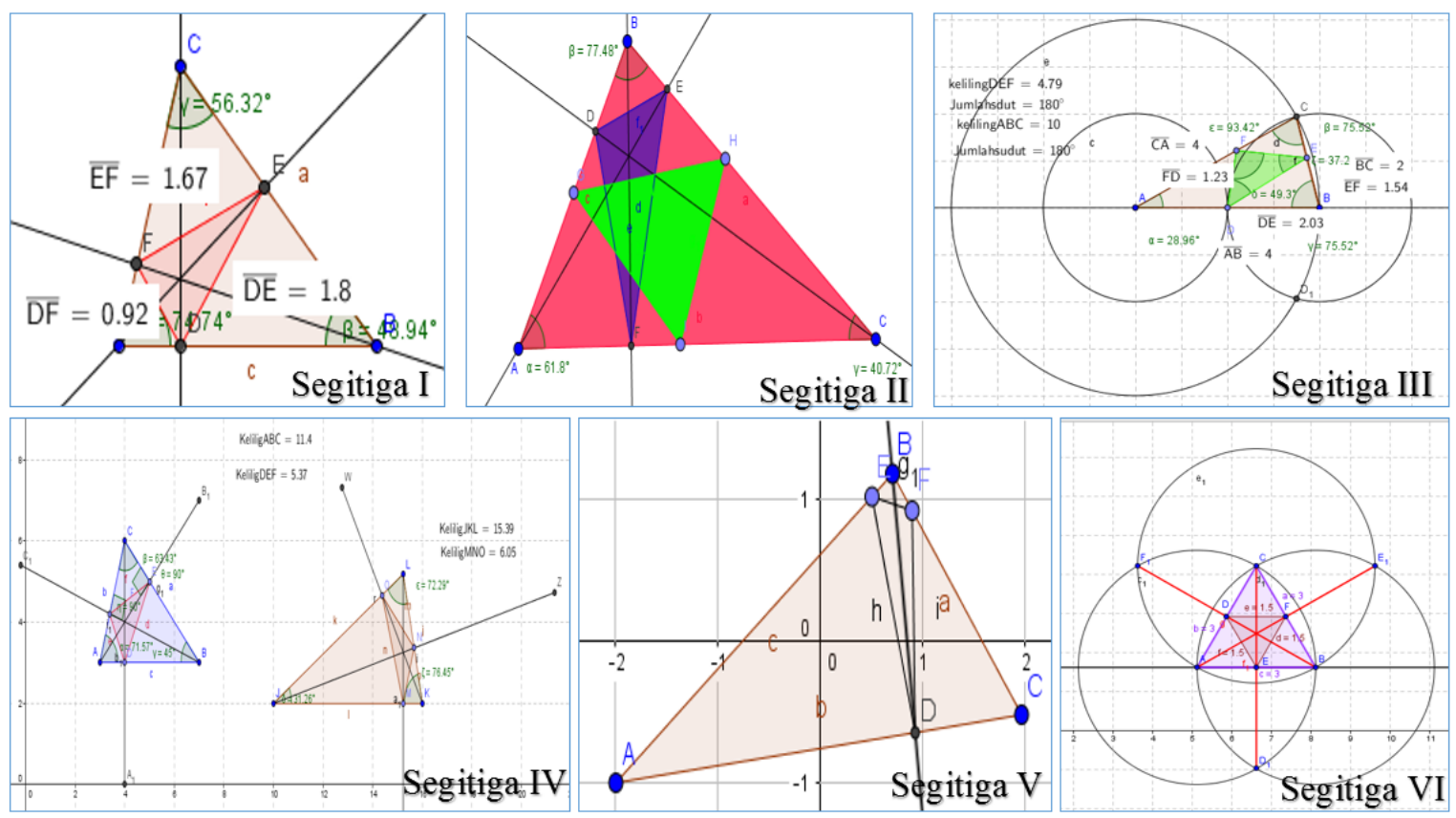

Gambar . Contoh konstruksi geogebra untuk masalah keliling segitiga

Gambar 5 tersebut menunjukkan adanya kesamaan pola pikir untuk menyelesaikan masalah tersebut yang diperkuat dengan penjelasan argumen sebagai berikut. Pada segitiga I, mahasiswa menyatakan "Karena titik DEF saling berdekatan diperoleh dari titik potong garis yang tegak lurus dengan tiap sisi pada segitiga 
maka keliling segitiganya minimum“. Argumentasi tersebut juga diberikan oleh mahasiswa yang menyelesaiakan konstruksi segitiga II, perbedaannya hanya pada penggunaan segitiga pembanding (berwarna hijau). Argumentasi mahasiswa untuk segitiga V yaitu "titik D pada segitiga ABC harus merupakan garis tinggi terhadap titik $\mathrm{B}$ dan untuk titik $\mathrm{E}$ dan titik $\mathrm{F}$ kita dapat memindahkan titik-titik tersebut sehingga diperoleh keliling segitiga DEF yang minimum“. Argumentasi yang cukup baik diberikan untuk konstruksi segitiga V sebagai berikut " titik D pada segitiga ABC diatas harus merupakan garis tinggi terhadap titik B dan untuk titik $\mathrm{E}$ dan titik F kita dapat memindahkan titik-titik tersebut sehingga diperoleh keliling segitiga DEF yang minimum“. Namun pada segitiga VI, mahasiswa menggunakan segitiga sama sisi yang tidak disertai argumen yang benar sebagai berikut "jika kita menggeser posisi masing-masing titik sudut sehingga bangunnya berubah maka keliling bangun tersebut akan bertambah besar. Hal ini dikarenakan panjang sisi bangun tersebut tidak sama sehingga ada sisi-sisi yang semakin panjang mengakibatkan keliling menjasi lebih besar." Fitur-fitur Geogebra yang digunakan untuk investigasi masalah ini meliputi ukuran sudut, bentuk poligon, lingkaran, panjang ruas garis dan garis-garis saling tegak lurus.

Identifikasi aktivitas investigasi berbantuan Geogebra untuk keseluruhan permasalahan yang ditugaskan pada penelitian ini sebagai berikut :

1) Mahasiswa memanfaatkan fitur-fitur Geogebra dengan baik untuk menyelesaikan permasalahan namun masih dipengaruhi oleh dimensi pengukuran belum dengan baik menggunakan konsep dan sifat-sifat geometri bidang, artinya kemampuan konstruksi belum optimal berkembang selama menggunakan Geogebra

2) Mahasiswa cenderung menggunakan strategi coba-coba (trial and error) selama investigasi menggunakan Geogebra karena mudah dan dapat dilakukan dengan cepat

3) Mahasiswa menggunakan prinsip konstruksi dengan cukup baik

4) Mahasiswa mampu menuliskan dengan sistematis tahapan investigasi yang dilakukan

Angket respon diberikan kepada mahasiswa setelah menyelesaikan tiga permasalahan yang diberikan untuk mengetahui aktivitas apa yang dilakukannya selama proses investigasi. Hasil respon disajikan dalam tabel berikut.

Tabel 1. Hasil respon mahasiswa tentang proses investigasi

\begin{tabular}{|c|c|c|c|c|}
\hline & PERTANYAAN & TIDAK & YA & RAGU \\
\hline \multicolumn{5}{|c|}{ Apa yang Anda lakukan sebelum menjawab soal? } \\
\hline 1 & Saya membaca soal lebih dari satu kali & $0.0 \%$ & $92.3 \%$ & $3.8 \%$ \\
\hline 2 & $\begin{array}{l}\text { Saya bertanya pada diri sendiri apakah saya paham dengan apa yang } \\
\text { ditanyakan }\end{array}$ & $7.7 \%$ & $50.0 \%$ & $38.5 \%$ \\
\hline 3 & Saya mencoba memahami menggunakan bahasa saya sendiri & $0.0 \%$ & $88.5 \%$ & $7.7 \%$ \\
\hline 4 & $\begin{array}{l}\text { Saya bertanya pada diri sendiri apa yang harus diketahui untuk } \\
\text { menjawab soal ini }\end{array}$ & $19.2 \%$ & $65.4 \%$ & $11.5 \%$ \\
\hline 5 & Saya mencoba mengingat apakah saya pernah mencoba soal seperti ini & $11.5 \%$ & $69.2 \%$ & $15.4 \%$ \\
\hline \multicolumn{5}{|c|}{ Apa yang Anda lakukan selama menjawab soal? } \\
\hline 6 & Saya memikirkan tentang langkah-langkah yang harus ditempuh & $0.0 \%$ & $84.6 \%$ & $11.5 \%$ \\
\hline 7 & Saya ingat kembali ke soal setelah bekerja selangkah & $7.7 \%$ & $53.8 \%$ & $34.6 \%$ \\
\hline 8 & Saya memeriksa setiap langkah pekerjaan yang saya lakukan & $7.7 \%$ & $46.2 \%$ & $42.3 \%$ \\
\hline 9 & Ketika saya harus memeriksa langkah kerja saya & $7.7 \%$ & $80.8 \%$ & $7.7 \%$ \\
\hline \multicolumn{5}{|c|}{ Apa yang Anda lakukan setelah selesai menjawab soal? } \\
\hline 10 & $\begin{array}{l}\text { Saya cocokkan kembali dengan yang ditanyakan untuk memastikan } \\
\text { jawaban saya benar }\end{array}$ & $0.0 \%$ & $76.9 \%$ & $19.2 \%$ \\
\hline 11 & Saya memeriksa kembali hitungan yang saya lakukan & $3.8 \%$ & $53.8 \%$ & $38.5 \%$ \\
\hline 12 & Saya mencoba menjawab dengan cara lain & $19.2 \%$ & $23.1 \%$ & $53.8 \%$ \\
\hline \multicolumn{5}{|c|}{ Apakah Anda menggunakan cara berikut dalam bekerja? } \\
\hline 14 & Saya menggambarnya untuk mudah memahaminya & $7.7 \%$ & $42.3 \%$ & $46.2 \%$ \\
\hline 15 & Saya menebak-nebak jawaban dan mencocokkan hasilnya & $15.4 \%$ & $34.6 \%$ & $46.2 \%$ \\
\hline 16 & Saya membuat daftar atau tabel untuk memudahkannya & $26.9 \%$ & $11.5 \%$ & $57.7 \%$ \\
\hline 17 & Saya bingung dan tidak tahu apa yang harus dikerjakan & $26.9 \%$ & $19.2 \%$ & $50.0 \%$ \\
\hline 18 & Saya menulis informasi penting yang diperlukan & $3.8 \%$ & $50.0 \%$ & $42.3 \%$ \\
\hline
\end{tabular}


Berdasarkan hasil respon tersebut terlihat bahwa aktivitas-aktivitas investigasi yang paling banyak dilakukan mahasiswa untuk memecahkan masalah sebagai berikut.

a. Mahasiswa memahami permasalahan yang diberikan melalui proses membaca permasalahan berulang kali $(92,3 \%)$, mencoba mengidentifikasi informasi yang dibutuhkan untuk menyelesaikan masalah $(65,4 \%)$ dan permasalahan apa yang harus diselesaikan $(50 \%)$, menyatakan ulang permasalahan dengan kalimat berbeda $(88,5 \%)$, dan membandingkan dengan permasalahan yang pernah diselesaikan sebelumnya $(69,2 \%)$.

b. Adapun strategi pemecahan masalah yang dilakukan oleh lebih dari $30 \%$ mahasiswa yaitu menggambar permasalahan, menebak-nebak jawaban dan mencatat informasi yang diperlukan, sedangkan membuat daftar/tabel hanya dilakukan oleh $11,5 \%$ mahasiswa. Lebih dari $60 \%$ mahasiswa masih mengalami kebingungan dengan strategi yang tepat.

c. Pada proses menggunakan strategi pemecahan masalah, mahasiswa umumnya memikirkan terlebih dulu strategi yang tepat $(84,5 \%)$ namun kurang dari $50 \%$ yang melakukan pemeriksaan langkah-langkah strategi yang telah dikerjakan.

d. Mahasiswa setelah menemukan solusi dari permasalahan, sebagian telah melakukan pemeriksaan perhitungan $(53,8 \%)$ dan mencocokkan kembali dengan permasalahan $(76,9 \%)$ namun hanya sekitar $23 \%$ yang mencoba strategi lain untuk menyelesaikan masalah yang sama.

\section{KESIMPULAN}

Kesimpulan yang diperoleh pada penelitian ini bahwa investigasi berbantuan Geogebra yang dilakukan oleh mahasiswa untuk menyelesaikan permasalahan konstruksi geometri bidang terdiri dari aktivitas-aktivitas berikut :

1) Membaca permasalahan lebih dari satu kali untuk mengidentifikasi informasi yang dibutuhkan dan permasalahan yang harus diselesaikan

2) Menuliskan kembali permasalahan dengan bahasa sendiri sehingga dapat menuliskan secara sistematis langkah-langkah investigasi

3) Membandingkan proses konstruksi manual dan berbantuan Geogebra yang pernah dilakukan untuk menyelesaikan permasalahan baru.

4) Mengidentifikasi sifat dan prinsip obyek geometri yang sesuai dengan permasalahan konstruksi

5) Melakukan strategi coba-coba (trial and error) untuk menyelesaikan permasalahan.

\section{DAFTAR PUSTAKA}

Haja, S. (2005). Investigating the Problem Solving Competency of Preservice Teachers in Dynamic Geometry Environment. the 29th Conference of the International Group for the Psychology of Mathematics Education. 3, pp. 81 - 87. Melbourne: PME (Psychology of Mathematics Education).

Hasek, R. (2013). Systems of Computer Algebra and Dynamic Geometry as Tools of Mathematical Investigation. International Journal for Technology in Mathematics Education, 20(3), 103 - 108.

Kennedy, L. M., Tipss, S., \& Johnson, A. (2008). Guiding Children's Learning of Mathematics. California: Thomson Wadsworth - Thomson Higher Education.

Ozen, D., \& Kose, N. Y. (2013). Investigating Pre-Service Mathematics Teachers' Geometric Problem Solving Process in Dynamic Geometry Environtment. Turkish Online Journal of Qualitative Inquiry, July 2013, 4(3)

Stiggins, R. J. (1994). Student-Centered Classroom Assessment. New Jersey: Prentice-Hall, Inc.

Subramanian, L. (2005). An Investigation of High School Geometry Students Proving and Logical Thinking Abilities and The Impact of Dynamic Geometry Software on Student Performance. Florida: University of Central Florida.

Van de Walle, J. A. (2008). Matematika Sekolah Dasar dan Menengah : Pengembangan Pengajaran Jilid 1. (Suyono, Trans.) Jakarta: Penerbit Erlangga.

Yanik, A. \& Ada, T. (2013). Investigation of the Development of 7th Grade Students' Skills to Define, Construct and Clasify Polygns with Cabri Geometry. Turkish Online Journal of Qualitative Inquiry, July 2013, 4(3). 